Praca poglądowa/Review

\title{
Przeciwciała monoklonalne w leczeniu ostrych białaczek limfoblastycznych
}

\section{Monoclonal antibodies in the treatment of acute lymphoblastic leukemias}

\author{
Beata Piątkowska-Jakubas* \\ Katedra i Klinika Hematologii, Uniwersytet Jagielloński Collegium Medicum, Kierownik: Prof. dr hab. med. Aleksander \\ B. Skotnicki, Kraków, Polska
}

IN F ORMACJE O ARTYKULE

Historia artykułu:

Otrzymano: 31.05 .2013

Zaakceptowano: 03.07.2013

Dostępne online: 19.07.2013

Słowa kluczowe:

- ostra białaczka limfoblastyczna

- ALL

- leczenie celowane

Keywords:

- Acute Lymphoblastic Leukaemia

- All

- targeted treatment

\begin{abstract}
A B S T R A C T
Several monoclonal antibody-based agents have potential application in the treatment of acute lymphoblastic leukemia (ALL) and bring the promise of increased response rates without excessive toxicity. These include unconjugated monoclonal antibodies, monoclonal antibodies or fragments linked to cytotoxic agents or conjugated to toxins (immunotoxins), bispecific single-chain antibodies that redirect cytotoxic T lymphocytes (via CD3 expression) to surface ALL antigens (eg. CD19) and bispecific T-cell engagers.

Monoclonal antibody-based reagents react with blasts by direct and/or indirect mechanisms. Binding by unconjugated monoclonal antibodies directly induce cytotoxicity through inhibition of proliferation or triggering of cell death pathways. Indirect killing may occur via antibody-dependent cell-mediated cytotoxicity and/or complementdependent cytotoxicity. The cytotoxicity of monoclonal antibodies can increase by linkage to chemotherapy agents and bacterial toxins therefore they do not require active immune response mechanisms for activity and can be effective even in profoundly immunocompromised patients.

Herein, we will review the results and status of investigational monoclonal antibodybased therapies in ALL.

C 2013 Polskie Towarzystwo Hematologów i Transfuzjologów, Instytut Hematologii i Transfuzjologii. Published by Elsevier Urban \& Partner Sp. z o.o. All rights reserved.
\end{abstract}

\section{Wstęp}

Stosowana dotychczas chemioterapia wielolekowa w ostrej białaczce limfoblastycznej (ALL) u dorosłych chorych w znacznej części naśladuje programy lecznicze stosowane w leczeniu ALL u dzieci i pozwala na osiągnięcie wyleczenia u 35-50\% chorych [1, 2]. Dodanie do leczenia u dorosłych chorych nowych leków, jak L-asparaginaza (także w formie pegylowanej), oraz intensyfikacja leczenia poremisyjnego poprawiły wyniki końcowe, ale kosztem zwiększenia toksyczności leczenia zwłaszcza u chorych powyżej 45. roku życia i starszych [3]. Dalsza intensyfikacja programów chemioterapeutycznych znajduje więc ograniczenie w postaci

* Adres do korespondencji: Katedra i Klinika Hematologii UJ CM, ul. Kopernika 17, 31-501 Kraków, Polska.

Adres email: bjakubas@wp.pl. 
nieakceptowalnej toksyczności. Należy podkreślić, że dzieci wyleczone z ALL narażone są na późne powikłania związane w części z intensywnością przebytego leczenia [4].

Istnieje więc potrzeba poszukiwania nowych leków w celu przełamania chemiooporności oraz poprawy efektów leczenia z jednoczesną redukcją toksyczności wczesnej oraz powikłań odległych.

Terapia celowana poprawiła wyniki leczenia ALL u dzieci i u dorosłych. Zastosowanie inhibitorów kinazy tyrozynowej BCR-ABL w połączeniu $\mathrm{z}$ chemioterapią $\mathrm{u}$ chorych na ALL z obecnością chromosomu Philadelphia poprawiło wskaźnik przeżycia z poniżej $10 \%$ do $50 \%$ [5-7].

Terapia celowana $\mathrm{z}$ użyciem przeciwciał monoklonalnych skierowanych przeciw markerom powierzchniowym komórek blastycznych w ALL w dotychczasowych badaniach wykazała obiecujące rezultaty. Poniżej przedstawione zostało ich omówienie.

\section{Przeciwciała monoklonalne nieskoniugowane}

\section{Rytuksymab}

Najwięcej doświadczeń dotyczy zastosowania rytuksymabu w połączeniu z chemioterapią u chorych na ALL z dojrzałych limfocytów B (B-ALL) i chłoniaka Burkitta charakteryzujących się wysoką ekspresją antygenu CD20 na komórkach blastycznych. 51 pacjentów otrzymało chemioterapię hyperCVAD poprzedzoną dwoma dawkami rytuksymabu, stosowano 4 cykle leczenia łącznie $\mathrm{z}$ ośmioma dawkami rytuksymabu. Odsetek całkowitych remisji (CR) wynosił 95\%, a 4-letni czas przeżycia 77\% i był znamiennie korzystniejszy w porównaniu $z$ grupą leczoną bez rytuksymabu $(p=0,03)$.

Znaczna poprawa wskaźnika 4-letniego przeżycia dotyczyła chorych powyżej 60. rż. i wynosiła odpowiednio w grupie bez i z dodaniem rytuksymabu $75 \%$ vs $19 \%$ $(\mathrm{p}<0,01)[8]$.

Podobne wyniki uzyskała grupa niemiecka GMALL-B-ALL/ NHL, stosując rytuksymab w połączeniu $\mathrm{z}$ chemioterapią w grupie 146 chorych. Wskaźnik CR wyniósł 90\%, 3-letnie przeżycie chorych poniżej 55. rż. wyniosło $91 \%$ us chorych w wieku 55 lat i powyżej - 84\%. W grupie chorych z B-ALL odsetek wyniósł CR 83\%, a 3-letnie przeżycie chorych młodszych $79 \%$ us $39 \%$ w grupie pacjentów starszych [9].

Również dane prezentowane przez grupę CALGB wykazały przewage chemioterapii $\mathrm{z}$ dodaniem rytuksymabu $\mathrm{w}$ porównaniu z historycznymi wynikami leczenia u pacjentów z B-ALL i chłoniakiem Burkitta. Wskaźniki przeżycia wynosiły w grupie historycznej 50\%, w grupie leczonej z użyciem rytuksymabu 90\% (chorzy niskiego ryzyka), 70\% (pośredniego ryzyka) i 50\% (wysokiego ryzyka) [10]. Dane te wskazują, że $\mathrm{w}$ tej grupie chorych rytuksymab powinien być standardowo stosowany w połączeniu $\mathrm{z}$ chemioterapią.

Rytuksymab stosowano również $\mathrm{u}$ pacjentów $\mathrm{z}$ de novo CD20+ pre-B-ALL w podobnym układzie w połączeniu $z$ chemioterapią hyperCVAD. W porównaniu z chorymi leczonymi w przeszłości bez rytuksymabu wyniki były znamiennie lepsze: CR 95\%, wskaźniki 3-letniego czasu trwania remisji i całkowitego przeżycia wynosiły odpowiednio 60 i $50 \%$. Korzyść z chemioimmunoterapii odnieśli chorzy poniżej 60. rż.
Wskaźnik CR wynosił w tej grupie $70 \%$ us 38\% w grupie historycznej $(p<0,01)$, a przeżycie całkowite $75 \%$ us $47 \%$ ( $p=0,003)$. W grupie chorych w wieku 60 lat i powyżej dodanie rytuksymabu nie poprawiło wyników leczenia ze względu na wyższy odsetek zgonów w CR z powodu infekcji [11]. Podobne wyniki badania GMALL 07/2003 opublikowała grupa niemiecka. Rytuksymab zastosowano w połączeniu $\mathrm{z}$ chemioterapią u pacjentów ALL standardowego ryzyka (łącznie 8 dawek) oraz w grupie wysokiego ryzyka (3 dawki) przed wykonaniem alloHSCT. W grupie chorych poniżej 55. rż. dodanie rytuksymabu poprawiło znamiennie wyniki leczenia: 5-letni czas trwania remisji wynosił $80 \%$ us $47 \%$ bez rytuksymabu, a 5 -letnie przeżycie odpowiednio $71 \%$ us 51\% [12].

Wyniki badań wskazują, że zastosowanie chemioimmunoterapii w CD20+ pre-B-ALL znamiennie poprawia odsetek remisji oraz wskaźniki przeżycia w grupie chorych młodszych (poniżej 55. rż.). W opracowaniu nowych algorytmów leczenia dla starszej grupy wiekowej należałoby zmniejszyć intensywność chemioterapii i/lub zredukować intensywność dawkowania rytuksymabu $\mathrm{w}$ celu zmniejszenia ryzyka powikłań infekcyjnych.

\section{Alemtuzumab (antyCD52)}

Doniesienia na temat skuteczność stosowania alemtuzumabu u chorych z ALL są pojedyncze i dotyczą niewielkich grup pacjentów. W badaniu pilotażowym leczono 24 chorych z noworozpoznaną ALL, którzy osiągnęli CR po chemioterapii. Alemtuzumab podawano w dawce $30 \mathrm{mg} \mathrm{w}$ iniekcji podskórnej trzy razy w tygodniu do osiągnięcia 12 dawek. Uzyskano obniżenie średnio o 1-log poziomu minimalnej choroby resztkowej. Po osiągnięciu mediany czasu obserwacji wynoszącej 51 mies., mediana DFS wynosiła 53 mies. a mediana przeżycia 55 mies. [13]. Opisano jedynie pojedyncze przypadki osiągnięcia CR po zastosowania monoterapii alemtuzumabem w pre-B-ALL [14].

\section{Epratuzumab (humanizowane przeciwciało antyCD22)}

Epratuzumab jest nieskoniugowanym humanizowanym przeciwciałem skierowanym przeciwko antygenowi CD22. Skuteczność preparatu w monoterapii oceniano u dzieci $\mathrm{z}$ pre-B-ALL w pierwszej wznowie. Stosowano 4 podania leku w dawce $360 \mathrm{mg} / \mathrm{m}^{2}$ i.v. w monoterapii, a następnie raz w tygodniu przez 4 tygodnie w połączeniu ze standardową czterolekową chemioterapią reindukującą. Tylko jeden chory spośród 15 leczonych epratuzumabem w monoterapii uzyskał częściową remisję. Dodanie epratuzumabu do chemioterapii reindukującej nie poprawiło odsetka remisji, natomiast u chorych, którzy osiągnęli CR, zwiększyło prawdopodobieństwo negatywizacji MRD [15].

\section{Przeciwciała monoklonalne bispecyficzne}

\section{Blinatumomab}

Blinatumomab (B-lineage-specific antitumor mouse monoclonal antibody) jest bispecyficznym przeciwciałem antyCD3/ antyCD19 angażującym receptor limfocytu $\mathrm{T}$ oraz antygen 
CD19 na powierzchni komórki białaczkowej. Antygen CD19 jest wysoce konserwatywnym receptorem transbłonowym obecnym na wszystkich limfocytach w chłoniakach i ostrych białaczkach B liniowych. W warunkach fizjologicznych wspólnie z CD21 i CD81 pełni on funkcję cząsteczki kostymulujacej dla receptora limfocytu B.

W odróżnieniu od komercyjnie dostępnych przeciwciał monoklonalnych blinatumomab jest białkiem fuzyjnym o masie $55 \mathrm{kDa}$, złożonym z rekombinowanych hyperzmiennych regionów dwóch pojedynczych łańcuchów przeciwciał monoklonalnych (scFvs) - CD19 i CD3 połączonych z 5 aminokwasowym łańcuchem [16]. Połączenie z łańcuchem aminokwasowym nadaje przeciwciału właściwość rotacji i elastyczność konieczne dla efektywnego jednoczesnego wiązania epitopów CD19 i CD3 na powierzchni komórki [16]. Po podaniu blinatumomabu dochodzi do szybkiej (w ciągu kilku minut) aktywacji limfocytów T i realizacji efektu cytotoksycznego poprzez układ perforyna-granzym w stosunku do komórek mających antygen CD19. Działanie blinatumomabu jest wysoce specyficzne, a do aktywacji poliklonalnych limfocytów $\mathrm{T}$ poprzez kompleks sygnałowy CD3 dochodzi jedynie w obecności antygenu CD19 [17].

Po podaniu blinatumomabu pacjentom w czasie pierwszej doby leczenia obserwuje się gwałtowne obniżenie się liczby limfocytów B we krwi obwodowej, w ciągu 48 godzin ich liczba spada poniżej progu detekcji i utrzymuje się na tym poziomie przez cały czas podawania leku. Zjawisko to jest związane z apoptozą limfocytów B. Niska dawka blinatumomabu jest zdolna wywołać silny efekt cytolityczny poprzez aktywację limfocytów $\mathrm{T}$ z udziałem jedynie kilku podjednostek receptora CD3, przy czym limfocyty T zachowują zdolność do proliferacji w miejscu aktywacji $[18,19]$.

Blinatumomab ma krótki okres półtrwania i musi być podawany w ciągłej infuzji dożylnej przez minimum 4 tygodnie. W czasie krótszej infuzji (2-4 godz.) obserwowano $\mathrm{u}$ chorych niekorzystne działanie związane $\mathrm{z}$ zespołem uwalniania cytokin [16].

W ostatnim czasie ukazało się doniesienie $\mathrm{z}$ ośrodka pediatrycznego o wystąpieniu u pacjenta w 1. dobie leczenia, po 7 godzinach od rozpoczęcia wlewu, zespołu uwalniania cytokin o ciężkim przebiegu $z$ wysokimi poziomami interleukiny-6, interleukiny-10 oraz interferonu $\gamma$. U chorego doszło do wystąpienia pełnoobjawowego zespołu aktywacji makrofagów/limfohistiocytozy hemofagocytowej (MAS/HLH) spełniającego wszystkie kryteria kliniczne i laboratoryjne i niereagującego na leczenie wysokimi dawkami sterydów. Radykalną poprawę, z ustąpieniem wszystkich objawów zespołu niewydolności wielonarządowej, uzyskano po zastosowaniu pojedynczej dawki inhibitora receptora IL-6 tocilizumabu. Autorzy sugerują celowość badań przesiewowych w kierunku obecności genów odpowiedzialnych za występowanie HLH u chorych leczonych terapiami aktywującymi limfocyty $\mathrm{T}$ [20].

Grupa niemiecka podsumowała wyniki badania 2 fazy $\mathrm{z}$ zastosowaniem blinatumomabu użytego u chorych na B komórkową ALL z przetrwałą na poziomie molekularnym minimalną chorobą resztkową (MRD) po I bloku konsolidacji lub wznową molekularną w każdym momencie od zakończenia I konsolidacji.

Leczenie blinatumomabem zakończyło 20 z 21 włączonych chorych, u 15/21 chorych obecna była przetrwała MRD, u pozostałych 5 chorych stwierdzono wznowę na poziomie MRD bez wznowy hematologicznej. Pacjenci otrzymali 4 cykle terapii składające się z 4 tygodni ciągłego wlewu dożylnego preparatu w dawce $15 \mu \mathrm{g} / \mathrm{m}^{2} /$ dobę i 2 tygodni przerwy. $80 \%$ chorych osiągnęło całkowitą remisję molekularną po 1 cyklu, czas przeżycia wolny od wznowy wynosił 19 mies. u chorych $z$ odpowiedzią us 3,2 mies. u chorych bez odpowiedzi (mediana czasu obserwacji 33 mies.). U 9 chorych mających dawcę wykonano allogeniczne przeszczepienie komórek hematopoetycznych (allo-HSCT), 6 z nich pozostaje w całkowitej remisji po transplantacji, u 2 chorych doszło do wznowy, 1 zmarł w przebiegu choroby przeszczep-przeciw-gospodarzowi. W grupie 11 chorych, u których nie wykonano allo-HSCT, 6 utrzymuje CR. Wyniki te są zachęcające, zwłaszcza jako leczenia eradykującego MRD $\mathrm{u}$ chorych $\mathrm{z}$ wysokim ryzykiem wznowy oraz w kontekście planowanego wykonania allo-HSCT [21, 22].

Grupa niemiecka przeprowadziła również badanie 2 fazy z blinatumomabem u 36 chorych z oporną i nawrotową B-komórkową ALL. Optymalna ustalona dawka leku wynosiła $5 \mu \mathrm{g} / \mathrm{m}^{2} /$ dobę w 1 . tygodniu i $15 \mu \mathrm{g} / \mathrm{m}^{2} /$ dobę w kolejnych cyklach leczenia. Całkowitą remisję hematologiczną osiągnięto u 72\% ( $n=26)$ chorych, co więcej, u 24 (92\%) chorych spełnione były kryteria remisji molekularnej (poziom MRD $\left.<10^{-4}\right)$.

Najwyższy odsetek CR uzyskano u chorych leczonych w pierwszym us kolejnym nawrocie (20/21 chorych, CR 95\% us $6 / 15$, CR $40 \%)$. All-HSCT wykonano u 13/26 chorych, którzy odpowiedzieli na leczenie, $\mathrm{z}$ wyjątkiem 1 chorego wszyscy pozostawali w CR przy medianie czasu obserwacji wynoszącej 10,7 mies. W grupie pozostałych 13 chorych, u których nie wykonano all-HSCT, u 8 (61,5\%) doszło do wznowy.

Mediana całkowitego czasu przeżycia u pacjentów, którzy odpowiedzieli na terapię, wynosiła 14,1 mies. natomiast w przypadku braku odpowiedzi 9,8 mies. [23].

\section{Przeciwciała skoniugowane z cytostatykami}

\section{Inotuzumab ozogamycyna}

Inotuzumab ozogamycyna jest humanizowanym przeciwciałem monoklonalnym skierowanym przeciw antygenowi powierzchniowemu CD22, sprzężonym z kalicheamycyną, substancją o silnych właściwościach cytotoksycznych. Inotuzumab wprowadza toksynę do komórki, ponieważ ma subnanomolarne powinowactwo $\mathrm{z}$ receptorem CD22. Wysoką skuteczność leku stosowanego w monoterapii wykazano w badaniach fazy I i II u chorych na B-komórkowe chłoniaki nieziarnicze, wskaźnik całkowitych odpowiedzi wynosił 60$80 \%$ (stosowana dawka $1,8 \mathrm{mg} / \mathrm{m}^{2}$ i.v. co 3-4 tygodni) [24].

Wyniki tych prób były podstawą dla przeprowadzenia badania II fazy $\mathrm{z}$ inotuzumabem w grupie 49 chorych (wiek 6-80, mediana 36 lat) na nawrotowe i oporne białaczki limfoblastyczne, u 75\% pacjentów było to leczenie ratunkowe 3. linii, 30\% stanowili chorzy wysokiego ryzyka cytogenetycznego $z$ obecnością $\mathrm{t}(9 ; 22)$ oraz $\mathrm{t}(4 ; 11)$. Antygen CD22 we wszystkich przypadkach obecny był na co najmniej $50 \%$ komórek blastycznych. 28/49 (57\%) pacjentów uzyskało CR, 
u 19 (39\%) chorych nie uzyskano odpowiedzi, 2 (4\%) chorych zmarło w ciągu 4 tyg. od rozpoczęcia leczenia. 22 spośród 49 chorych włączonych do badania zostało zakwalifikowanych do allotransplantacji komórek hematopoetycznych [25].

Badania I i II fazy wskazują, że przeciwciało antyCD22 skoniugowane $\mathrm{z}$ kalicheamycyną stosowane w monoterapii, jest aktywnym lekiem w przypadku opornych i nawrotowych białaczek limfoblastycznych. Jakkolwiek należy stwierdzić, że odpowiedź w przypadku opornych i nawrotowych postaci ALL jest krótkotrwała, co jest najpewniej związane $\mathrm{z}$ biologią klonu opornego, tak więc w kolejnych badaniach inotuzumab powinien być wprowadzony we wcześniejszych etapach leczenia ratunkowego, a także w skojarzeniu $z$ chemioterapią.

\section{SAR3419}

SAR3419 jest humanizowanym przeciwciałem monoklonalnym antyCD19 skoniugowanym z toksyną (maytansyna) silnie uszkadzającą aparat mikrotubul. W badaniach I fazy lek stosowano w monoterapii w nawrotowych i opornych chłoniakach nieziarniczych B-komórkowych wskaźnik całkowitych odpowiedzi wynosił 74\%. Odpowiedź wyrażającą się regresją masy guza uzyskano u 7/15 (47\%) chorych opornych na wcześniejszą chemioimmunoterapię z użyciem rytuksymabu. Liczba podawanych cykli SAR3419 wynosiła maksimum 6 z częstością co 3 tygodnie, wyznaczono maksymalną dawkę tolerowaną (MTD) wynoszącą $160 \mathrm{mg} / \mathrm{m}^{2}$ [26]. Aktualnie trwa w ośrodku MD Anderson w USA nieopublikowane jeszcze badanie II fazy $u$ chorych na oporne i nawrotowe ALL, lek podawany jest $\mathrm{w}$ dawce $55-70 \mathrm{mg} / \mathrm{m}^{2}$ i.v. co tydzień przez 4 tygodnie do czasu osiągnięcia CR, a następnie co drugi tydzień przez 8 tygodni.

W najnowszych badaniach aktywność SAR3419 oceniono z użyciem modelu ksenograftu dziecięcej pre-B-ALL w monoterapii oraz w skojarzeniu z klasycznym systemem leczniczym stosowanym w indukcji remisji. SAR3419 znamiennie wydłużał czas do progresji w przypadku białaczek pre-BALL oraz ALL z obecnością mutacji genu MLL, odpowiedź znamiennie korelowała $\mathrm{z}$ poziomem ekspresji CD19 na komórkach blastycznych. SAR3419 wykazywał także skuteczność w przypadkach chemiooporności. Kontynuacja podawania SAR3419 po uzyskaniu remisji chemioterapią w skojarzeniu z SAR3419 zapobiegała nawrotom szpikowym i pozaszpikowym, z wyjątkiem zajęcia ośrodkowego układu nerwowego [27].

Dostępne są również połączenia przeciwciał monoklonalnych antyCD19 i antyCD22 z inną toksyną komórkową uszkadzającą aparat mikrotubul - aurystatyną, które mogą być przedmiotem badań klinicznych.

\section{Immunotoksyny}

\section{Moxetumomab pasudotox (HA22, CAT-8015)}

CAT-8015 jest rekombinowaną immunotoksyną drugiej generacji złożoną $\mathrm{z}$ pojedynczego łańcucha przeciwciała (scFv) o wysokim powinowactwie do cząsteczki CD22 i zmodyfikowanej cząsteczki egzotoksyny wytwarzanej przez szczep Pseudomonas, z której usunięto domenę umożliwiającą nieswoiste połączenie $\mathrm{z}$ błoną komórkową (Pseudomonas Exotoxin, PE38). Działanie cytotoksyczne toksyny jest spowodowane zahamowaniem czynnika translacyjnego (EF2; elongation factor 2) integralnego dla procesu translacji białek [28].

Wyniki badania I fazy z użyciem HA22, przedstawione w 2012 r. na kongresie ASCO, dotyczą grupy 42 chorych z opornymi postaciami białaczki włochatokomórkowej. Odsetek odpowiedzi ogółem (ORR) wynosił 88\%, w tym CR 55\%. Podczas terapii obserwowano toksyczność 3. i 4. stopnia wg WHO w postaci leukopenii, limfopenii oraz wzrostu gammaglutamylotransferazy, ale żadne z powikłań nie spełniało kryterium toksyczności ograniczającej dawkę (DLT; dose limiting toxicity), u 38\% chorych stwierdzono obecność przeciwciał neutralizujących toksynę [29].

Aktualnie trwa badanie I fazy $\mathrm{z}$ zastosowania HA22 w opornych postaciach ALL u dzieci. Wstępne wyniki są zachęcające: odpowiedź ogółem uzyskało 29\% (5/17) chorych w tym całkowitą remisję 24\% (4/17) chorych [30].

Dane dotyczące aktualnie toczących się badań I fazy dostępne są na stronie ClinicalTrials.gov Identifier: NCT00586924 oraz NCT00659425. Przeciwciała monoklonalne skierowane przeciw antygenom CD19 i CD22 związane z immunotoksyną błoniczą (diphtheria immunotoxin) są przedmiotem wczesnej fazy badań I/II fazy.

Ostatnio badaną immunotoksyną jest Combotox, który jest połączeniem dwóch immunotoksyn. Toksyną jest deglikozylowany łańcuch A rycyny (dgRTA) sprzężony z przeciwciałami antyCD22 (RFB4-dgRTA) i antyCD19 (HD37-dgRTA) w proporcji 1:1.

Opublikowano dotychczas wyniki 2 badań I fazy z użyciem Combotoxu u dzieci i dorosłych z opornymi i nawrotowymi ALL B-komórkowymi. W grupie pediatrycznej spośród 17 leczonych pacjentów u 3 (18\%) uzyskano CR, u pozostałych Combotox wykazał istotną aktywność hematologiczną, zmniejszając liczbę blastów w krwi obwodowej. Ustalono maksymalną dawkę tolerowaną wynoszącą $5 \mathrm{mg} / \mathrm{m}^{2}$ [31]. Podobne wyniki uzyskano w badaniu w grupie 17 chorych w wieku 19-72 lat. Oceniano toksyczność dawek eskalowanych: 3, 5, 6, 7 i $8 \mathrm{mg} / \mathrm{m}^{2}$, MTD wynosiła $7 \mathrm{mg} / \mathrm{m}^{2}$, objawem toksyczności ograniczającej dawkę był zespół przeciekania kapilar. Tylko 1 chory uzyskał częściową remisję, u wszystkich obserwowano obniżenie się odsetka komórek blastycznych [32].

\section{Przeciwciała monoklonalne antyCD1a uzyskane metodą prezentacji na fagach}

Atrakcyjnym celem terapii jest białko błonowe CD1a obecne na komórkach blastycznych T-komórkowej ALL w podtypie immunologicznym tzw. tymocytarnym korowym (cortical type). Przeciwciało monoklonalne CR2113 uzyskane z wykorzystaniem metody prezentacji na fagu zostało wybrane spośród 6 humanizowanych przeciwciał dostępnych w bibliotece fagów wykazujących wysoką specyficzność i awidność wobec różnych wariantów antygenu CD1.

Metoda phage display jest alternatywnym sposobem otrzymywania wysoce swoistych przeciwciał monoklonalnych. 
Proces selekcji zadanego przeciwciała polega na modyfikacji najmniejszego funkcjonalnie fragmentu przeciwciała odpowiedzialnego za rozpoznawanie antygenu, tzn. scFv (single chain fragment variable). Do regionów hiperzmiennych scFv wprowadza się losowo mutacje aminokwasowe, wytwarzając w ten sposób pulę wariantów przeciwciał o różnych sekwencjach prezentowanych na powierzchni fagu, co tworzy tzw. bibliotekę fagów. Zaletą obecnie stosowanej metody phage display jest możliwość uzyskania przeciwciał o wysokim powinowactwie do antygenu poprzez tzw. technikę dojrzewania powinowactwa. Poprzez tworzenie tzw. bibliotek II generacji otrzymuje się na bazie wyizolowanego przeciwciała warianty o zwiększonej sile oddziaływania $\mathrm{z}$ antygenem.

Przeciwciało CR2113 łączy się swoiście z cząsteczką CD1a obecną na komórkach linii białaczki ALL-T liniowej oraz na komórkach blastycznych pobranych od pacjentów. Powstanie kompleksu CD1a-CR2113 indukuje reakcję cytotoksyczną zależną od komplementu (CDC; complement-dependent cytotoxicity) oraz silną reakcję cytotoksyczną zależną od przeciwciał (ADCC; antibody-dependent cell cytotoxicity) [33].

\section{Chimeryczne receptory antygenowe (CAR; chimeric antigen receptor)}

Jest to nowa forma adoptywnej immunoterapii wykorzystująca potencjał cytotoksyczny autologicznych limfocytów $\mathrm{T}$, które poddaje się genetycznej modyfikacji w celu wytworzenia tzw. chimerycznego receptora antygenowego o wysokiej specyficzności wobec antygenów docelowych na komórkach białaczkowych. CAR składa się z domeny zewnątrzkomórkowej rozpoznającej antygen i jest to pojedynczy łańcuch zawierający region zmienny mysiego przeciwciała monoklonalnego (scFv) antyCD19 lub antyCD22 oraz wewnątrzkomórkowej domeny sygnałowej ¡CD3 połączonej z domeną kostymulującą 4-1BB lub CD28.

Chimeryczne receptory antygenowe mające 1 domenę kostymulującą CD28 określane są jako CAR II generacji, mające 2 domeny CD28 i 4-1BB - jako CAR III generacji.

Zależnie od użytego do kodowania plazmidu rozróżnia się: plazmidy II generacji wytwarzającej gen dla domeny CD28 i CD3- $\zeta$ lub CD28 i 4-1BB, plazmidy III generacji kodujące domeny CD28, 41BB (CD137) i łańcuch CD3- $\zeta$. Wektorami do transdukcji limfocytów $\mathrm{T}$ (autologicznych, uzyskanych $\mathrm{z}$ aferezy) uzyskanym genem są retrowirusy, lentiwirusy lub z wykorzystaniem transpozonów [34, 35].

W ostatnim okresie opublikowano dwa obiecujące doniesienia dotyczące użycia limfocytów $\mathrm{T}$ ze zmodyfikowanym antyCD19-CAR II generacji. Pierwsze z nich dotyczy chorych z CLL i chłoniakami z komórek B wykazujących oporność na wszystkie standardowe metody leczenia $\mathrm{z}$ wyjątkiem alloHSCT. Protokół badania ma kilka etapów: aferezę autologicznych limfocytów $\mathrm{T}$ w celu wytworzenia transdukowanych limfocytów T antyCD19-CAR, chemioterapię (wysokie dawki cyklofosfamidu i fludarabinę) z następową infuzją limfocytów T skojarzoną z podawaniem interleukiny-2.

Remisję uzyskano u 75\%, u 4 chorych obserwowano długotrwałą deplecję prawidłowych komórek linii B CD19+. W 4 przypadkach obserwowano odwracalną toksyczność związaną ze znacznym wzrostem poziomu cytokin w surowicy (TNF i interferonu $\gamma$ ) [36].

W maju 2013 r. ukazało się doniesienie o bardzo obiecujących wynikach zastosowania autologicznych limfocytów T

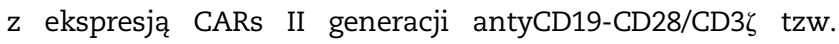
19-28z. Terapię zastosowano u 5 pacjentów $\mathrm{z}$ nawrotem B-ALL. Wszyscy chorzy w chwili włączenia do badania mieli aktywną chorobę lub wykazywali obecność MRD. Pod wpływem infuzji limfocytów T u wszystkich chorych obserwowano szybką redukcję masy guza i negatywizację MRD w badaniach molekularnych. Terapia była dobrze tolerowana, wzrost poziomu cytokin we krwi po infuzji limfocytów T ze zmodyfikowanym antyCD19-CAR oraz objawy zespołu uwalniania cytokin wymagające podawania sterydów występowały u chorych z nasileniem korelującym z masą guza.

Komórki białaczkowe chorego, u którego doszło do wznowy po infuzji limfocytów T ze zmodyfikowanym CAR, wykazywały nadal ekspresję antygenu CD19 i zachowały wrażliwość na reakcję cytotoksyczną zależną od limfocytów T ze zmodyfikowanym antyCD19-CAR [37].

W ostatnim czasie wytworzono CAR II generacji charakteryzujący się wysoką selektywnością i powinowactwem do epitopu antygenu CD22 i silnym efektem cytotoksycznym ocenianym $\mathrm{w}$ badaniach in vitro na liniach komórkowych białaczki limfoblastycznej i in vivo na modelu zwierzęcym [38].

Trwają dalsze badania nad skonstruowaniem optymalnego CAR. Badania na liniach komórkowych i na modelu zwierzęcym wskazują na wyższą aktywność CAR drugiej i trzeciej generacji w porównaniu z pierwszą (bez udziału domeny kostymulującej), ocenia się też różne warianty przeciwciał o wysokim powinowactwie do specyficznych dla komórek nowotworowych antygenów. Istnieją przesłanki, że podanie poprzedzającej infuzję chemioterapii (kondycjonującej) przedłuża czas utrzymywania się krążących limfocytów $\mathrm{T}$ z chimerycznym receptorem i tym samym zwiększa odpowiedź przeciwnowotworową. Nierozstrzygniętą kwestią pozostaje stosowanie po podaniu limfocytów cytokin wspomagających efekt przeciwnowotworowy (IL-2). Znacznym ograniczeniem dla ich stosowania jest niebezpieczeństwo wywoływania niekontrolowanych reakcji immunologicznych (np. CLS). Otwarte pozostaje pytanie, jakie skutki niesie terapia w kontekście planowania allotransplantacji komórek hematopoetycznych u chorych, którzy uzyskali remisję w wyniku leczenia $\mathrm{z}$ wykorzystaniem techniki CAR.

Wstępne badania kliniczne tej formy terapii u chorych ze skrajnie złym rokowaniem, którzy nie zareagowali na żadną $\mathrm{z}$ form konwencjonalnie dostępnych metod leczenia, są obiecujące, a objawy niepożądane i toksyczność akceptowalne.

\section{Wnioski}

1. Miejsce terapii celowanej przy użyciu przeciwciał monoklonalnych o różnym mechanizmie działania przeciwbiałaczkowego w planowaniu terapii nie jest ustalone.

2. $\mathrm{Na}$ podstawie dotychczasowych badań, wydaje się, że ograniczeniem dla tej formy terapii jest brak trwałości efektu przeciwnowotworowego. 
3. Najbardziej obiecujące dla kierunku przyszłych badań są doniesienia dotyczące działania przeciwciał bispecyficznych (blinatumomab) i limfocytów T-CAR, które ukierunkowują i potencjalizują odpowiedź cytotoksyczną realizowaną przez limfocyty $\mathrm{T}$ w stosunku do specyficznych antygenów komórek nowotworowych.

4. Istnieją silne przesłanki, że u chorych z aktywnym procesem białaczkowym terapia przeciwciałami monoklonalnymi powinna być kojarzona $\mathrm{z}$ chemioterapią, natomiast pacjenci $z$ chorobą obecną na poziomie MRD mogą odnieść korzyść z zastosowania przeciwciał monoklonalnych w monoterapii w celu eradykacji MRD i utrzymania tego efektu.

\section{Konflikt interesu/Conflict of interest}

Nie występuje.

\section{Finansowanie/Financial support}

Nie występuje.

\section{Etyka/Ethics}

Treści przedstawione $\mathrm{w}$ artykule są zgodne $\mathrm{z}$ zasadami Deklaracji Helsińskiej, dyrektywami EU oraz ujednoliconymi wymaganiami dla czasopism biomedycznych.

\section{PIŚ M I E N N I C T W O/REFERENCES}

[1] Bassan R, Hoelzer D. Modern therapy of acute lymphoblastic leukemia. JCO 2011;29:532-543.

[2] Faderl S, O'Brien S, Pui CH, et al. Adult acute lymphoblastic leukemia: Concepts and strategies. Cancer 2010;116: 1165-1176.

[3] Huguet F, Leguay T, Raffoux E, et al. Pediatric-inspired therapy in adults with Philadelphia chromosome-negative acute lymphoblastic leukemia: The GRAALL-2003 study. JCO 2009;27:911-918.

[4] Oeffinger KC, Mertens AC, Sklar CA, et al. Chronic health conditions in adult survivors of childhood cancer. N Engl J Med 2006;355:1572-1582.

[5] Ravandi F, O'Brien S, Thomas D, et al. First report of phase 2 study of dasatinib with hyper- CVAD for the frontline treatment of patients with Philadelphia chromosomepositive $(\mathrm{Ph}+)$ acute lympoblastic leukemia. Blood 2010;116:2070-2077.

[6] Bassan R, Rossi G, Pogliani EM, et al. Chemotherapy-phased imatinib pulses improve long-term outcome of adult patients with Philadelphia chromosome-positive acute lymphoblastic leukemia: Northern Italy Leukemia Group protocol 09/00. JCO 2010;28:3644-3652.

[7] Schultz KR, Bowman WP, Aledo A, et al. Improved early event-free survival with imatinib in Philadelphia chromosome-positive acute lymphoblastic leukemia: A Children's Oncology Group study. JCO 2009;27:5175-5181.

[8] Thomas D, O'Brien S, Kantarjian HM. Monoclonal antibody therapy with rituximab for acute lymphoblastic leukemia. Hematol Oncol Clin North Am 2009;23:949-971.
[9] Hoelzer D, Gökbuget N. Chemoimmunotherapy in acute lymphoblastic leukemia. Blood Rev 2012;26:25-32.

[10] Rizzieri DA, Johnson JL, Byrd JC, et al. Efficacy and toxicity of rituximab and brief duration, high intensity chemotherapy with filgrastim support for Burkitt or Burkitt-like leukemia/ lymphoma: Cancer and Leukemia Group B (CALGB) study 10002. Blood 2010;116:858.

[11] Thomas DA, O'Brien S, Faderl S, et al. Chemoimmunotherapy with a modified hyper-CVAD and rituximab regimen improves outcome in de novo Philadelphia chromosome-negative precursor B-lineage acute lymphoblastic leukemia. JCO 2010;28:3880-3889.

[12] Hoelzer D, Huettmann A, Kaul F, et al. Immunochemotherapy with rituximab improves molecular CR rate and outcome in CD20+ B-lineage standard and high risk patients: Results of $263 \mathrm{CD} 20+$ patients studied prospectively in GMALL study 07/2003. Blood 2010;116:170.

[13] Stock W, Sanford B, Lozanski G, et al. Alemtuzumab can be incorporated into front-line therapy of adult acute lymphoblastic leukemia (ALL): Final phase I results of a Cancer and Leukemia Group B study (CALGB 10102). Blood 2009;114:838.

[14] Laporte JP, Isnard F, Garderet L, et al. Remission of adult acute lymphocytic leukemia with alemtuzumab. Leukemia 2004;18:1557-1558.

[15] Raetz AE, Cairo MS, Borowitz MJ, et al. Reinduction chemoimmunotherapy with epratuzumab in relapsed acute lymphoblastic leukemia (ALL) in children, adolescents and young adults: Results from Children's Oncology Group (COG) study ADVL04P2. Blood 2011;118:573.

[16] Nagorsen D, Kufer P, Baeuerle PA, Bargou R. Blinatumomab: a historical perspective. Pharmacol Ther 2012;136:334-342.

[17] Bargou R, Leo E, Zugmaier G, et al. Tumor regression in cancer patients by very low doses of a $\mathrm{T}$ cell-engaging antibody. Science 2008;321:974-977.

[18] Brischwein K, Parr L, Pflanz S, et al. Strictly target celldependent activation of $\mathrm{T}$ cells by bispecific single-chain antibody constructs of the BiTE class. J Immunother 2007;30:798-807.

[19] Klinger M, Brandl C, Zugmaier G, et al. Immunopharmacologic response of patients with B-lineage acute lymphoblastic leukemia to continuous infusion of $\mathrm{T}$ cell-engaging CD19/CD3-bispecific BiTE antibody blinatumomab. Blood 2012;119:6226-6233.

[20] Teachey DT, Rheingold SR, Maude SL, et al. Cytokine release syndrome after blinatumomab treatment related to abnormal macrophage activation and ameliorated with cytokine directed therapy. Blood 2013 May 15. doi: 10.1182/ blood-2013-02-485623 [Epub ahead of print].

[21] Topp MS, Kufer P, Gökbuget N, et al. Targeted therapy with the T-cell-engaging antibody blinatumomab of chemotherapy-refractory minimal residual disease in B-lineage acute lymphoblastic leukemia patients results in high response rate and prolonged leukemia-free survival. JCO 2011;29:2493-2498.

[22] Topp MS, Gökbuget N, Zugmaier G, et al. Long-term followup of hematologic relapse-free survival in a phase 2 study of blinatumomab in patients with MRD in B-lineage ALL. Blood 2012;26:5185-5187.

[23] Topp MS, Gökbuget N, Zugmaier G, et al. Anti-CD19 BiTE blinatumomab induces high complete remission rate and prolongs overall survival in adult patients with relapsed/ refractory B-precursor acute lymphoblastic leukemia (ALL). ASH Ann Meet Abstr 2012;120:670.

[24] Advani A, Coiffier B, Czuczman M, et al. Safety, pharmacokinetics, and preliminary clinical activity of inotuzumab ozogamicin, a novel immunoconjugate for the 
treatment of B-cell non-Hodgkin's lymphoma: results of a phase I study. JCO 2010;28:2085-2093.

[25] Kantarjian H, Thomas D, Jorgensen J, et al. Inotuzumab ozogamicin, an anti-CD22-calecheamicin conjugate, for refractory and relapsed acute lymphocytic leukaemia: a phase 2 study. Lancet Oncol 2012;13:403-411.

[26] Younes A, Kim S, Romaguera J, et al. Phase I multidoseescalation study of the anti-CD19 maytansinoid immunoconjugate SAR3419 administered by intravenous infusion every 3 weeks to patients with relapsed/refractory B-cell lymphoma. JCO 2012;30:2776-2782.

[27] Carol H, Szymanska B, Evans K, et al. The anti-CD19 antibody-drug conjugate SAR3419 prevents hematolymphoid relapse postinduction therapy in preclinical models of pediatric acute lymphoblastic leukemia. Clin Cancer Res 2013;9:795-1805.

[28] Feld J, Barta SK, Schinke C, et al. Linked-in: design and efficacy of antibody drug conjugates in oncology. Oncotarget 2013;4:397-412.

[29] Kreitman RJ, Tallman MS, Robak T, et al. Phase I Trial of anti-CD22 recombinant immmunotoxin moxetumomab pasudotox (CAT-8015 or HA22) in patients with hairy cell leukemia. JCO 2012;30:1822-1828.

[30] Wayne AS, Bhojwani D, Silverman LB, et al. A novel antiCD22 immunotoxin, moxetumomab pasudotox: A phase I study in pediatric acute lymphoblastic leukemia. 53rd ASH Ann Meet 2011;248.

[31] Herrera L, Bostrom B, Gore L, et al. A phase I study of Combotox in pediatric patients with refractory B-lineage acute lymphoblastic leukemia. J Pediatr Hematol Oncol 2009;31:936-941.

[32] Schindler J, Gajavelli S, Ravandi F, et al. A phase I study of a combination of anti-CD19 and anti-CD22 immunotoxins (Combotox) in adult patients with refractory B-lineage acute lymphoblastic leukaemia. Br J Haematol 2011;154:471-476.

[33] Bechan GI, Lee DW, Zajonc DM, et al. Phage display generation of a novel human anti-CD1A monoclonal antibody with potent cytolytic activity. $\mathrm{Br} \mathrm{J}$ Haematol 2012;159:299-310.

[34] Brentjens RJ. CARs and cancers: questions and answers. Blood 2012;119:3872-3873.

[35] Haso W, Lee DW, Shah NN, et al. Anti-CD22-chimeric antigen receptors targeting B-cell precursor acute lymphoblastic leukemia. Blood 2013;121:1165-1174.

[36] Kochenderfer JN, Dudley ME, Feldman SA, et al. B-cell depletion and remissions of malignancy along with cytokine-associated toxicity in a clinical trial of anti-CD19 chimeric-antigen-receptor-transduced T cells. Blood 2012;119:2709-2720.

[37] Brentjens RJ, Davila ML, Riviere I, et al. CD19-Targeted T Cells Rapidly Induce Molecular Remissions in Adults with Chemotherapy-Refractory Acute Lymphoblastic Leukemia. Sci Transl Med 2013;5:177 ra38. http://dx.doi.org/10.1126/ scitranslmed.3005930.

[38] Haso W, Lee DW, Shah NN, et al. Anti-CD22-chimeric antigen receptors targeting B-cell precursor acute lymphoblastic leukemia. Blood 2013;121:1165-1174. 